\title{
DE HANDEL VAN JAVA IN 1890 EN VORIGE JAREN.
}

\author{
II.
}

Bij de behandeling der uitvoerartikelen ware eene rangschikking naar gelang van hunne herkomst, als voortbrengselen van de eigen landbouwnijverheid der inlandsche bevolking, of als resultaat van de particuliere landbouwondernemingen van Europeesche planters, zeker het meest eigenaardig; maar er zijn meerdere artikelen, waarbij in dit opzicht geene nauwkeurige schifting mogelijk is, en wij houden ons daarom aan de volgende, reeds vroeger gebezigde indeeling:

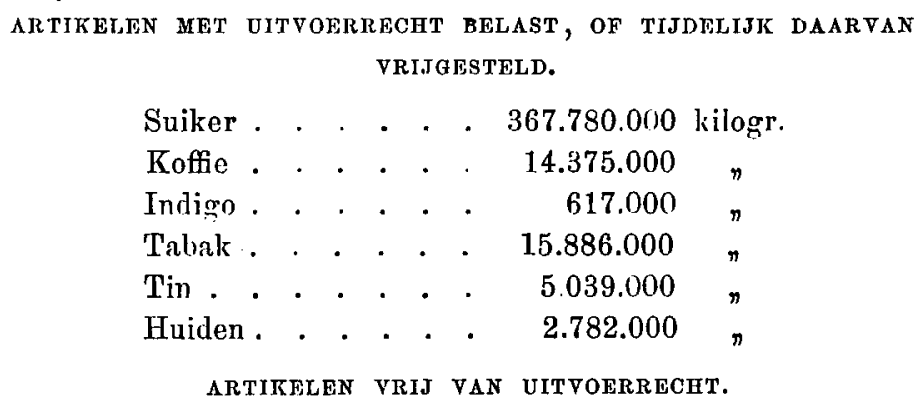


Boschproducten.

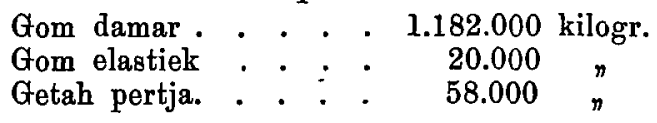

Diversen.

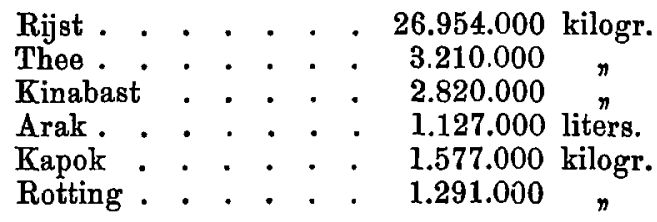

De bovenstaande cijfers hebben, zooals men ziet, uitsluitend betrekking op de uitgevoerde hoeveelheden, gelijk dit in de maandstaten van den aanvang hunner publicatie af steeds het geval is geweest, en dit maakt eene vergelijking met vroegere jaren uit den aard der zaak meer vertrouwbaar dan waar men, zooals bij het meerendeel der invoerartikelen, alleen kan afgaan op het waardebedrag, dat tengevolge van de steeds fluctueerende marktprijzen niet altijd als juiste maatstaf gelden kan. Bovendien hebben wij met betrekking tot de uitvoercijfers het groote voordeel van ze te kunnen toetsen aan de geheel zelfstandig samengestelde statistiek van de Handelsvereeniging te Batavia, zooals die door haren ijverigen secretaris, den heer A. D. J. Penn, met groote zorg geregeld bijgehouden, en in het bekende marktbericht dier vereeniging opgenomen wordt. Vroeger kwamen daarin ook overzichten van de voornaamste invoeren voor; maar van de bewerking hiervan is moeten worden afgezien sedert de uitgaaf gestaakt werd van de manifesten der naar Nederlandsch Indië verscheepte goederen, die eenige jaren achtereen bij de firma Nijgh en van Ditmar te Rotterdam het licht zagen.

Alleen de van regeeringswege openbaar gemaakte uitvoercijfers kunnen dus met andere gegevens worden vergeleken, eene gelegenheid waarvan wij zoo veel noodig partij zullen trekken bij hetgeen wij ten opzichte van de uitvoeren van Java hebben in het midden te brengen. 
SUIKER.

Wanneer wij de in kilogrammen uitgedrukte hoeveelheden van de regeeringsstatistiek herleiden tot het in den Indischen handel en verkeer meer gebruikelijke pikolgewicht, verkrijgen wij voor den uitvoer van de laatste tien jaren de volgende cijfers:

\begin{tabular}{|c|c|c|c|c|}
\hline 1881 & 4.370 .000 & pik. & 1886 & 5.420 .000 \\
\hline 1882 & 5.391 .000 & $n$ & 1887 & 6.265 .000 \\
\hline 1883 & 4.986 .000 & $\pi$ & 1888 & 6.084 .000 \\
\hline 1884 & 5.810 .000 & $n$ & 1889 & 5.113 .000 \\
\hline 1885 & 6.834 .000 & n & 1890 & 5.957 .000 \\
\hline
\end{tabular}

Volgens de statistiek van de Handelsvereeniging daarentegen zou de uitvoer van suiker hebben bedragen:

\begin{tabular}{|c|c|c|c|c|}
\hline 1881 & .000 & jik. & of 24300 & pik. $\min d$ \\
\hline 382 & 4.889 .000 & $n$ & 502.000 & $n$ \\
\hline 385 & 5.033 .000 & $n$ & 47.000 & meer \\
\hline 1884 & 5.636 .000 & $\pi$ & 174.000 & $\operatorname{mind} \mathrm{er}$ \\
\hline 885 & 6.593 .000 & $n$ & 241.000 & $n$ \\
\hline 1886 & 5.419 .000 & $n$ & 6.000 & $n$ \\
\hline 1887 & 6.642 .000 & n & 377.000 & $\eta \quad \mathrm{me \theta r}$ \\
\hline 888 & 6.202 .000 & $\pi$ & $\pi \quad 118.000$ & n \\
\hline & 5.885 .000 & $n$ & 772.000 & n \\
\hline & 6.180 .000 & $n$ & 223.000 & $"$ \\
\hline
\end{tabular}

dan de regeeringsstatistiek aangeeft, en voor deze verschillen een afdoende verklaring te geven is niet gemakkelijk. Opmerking verdient het, dat te beginnen met het jaar 1887, het jaar waarin het uitvoerrecht op suiker met ingang van 1 Juni voor den tijd van vijf jaren werd geschorst, de verschillen niet onbelangrijk grooter worden dan vroeger. Vóór dien tijd zijn de opgaven van de regeering, verband houdende met het betaalde uitvoerrecht, ongetwijfeld de juiste; maar sedert verviel dit middel van controle, en daarom verdienen voor het jaar 1887 en volgende jaren de inmiddels ook met grooter zorg dan vroeger bewerkte gegevens van de Handelsvereeniging 
zeker meer vertrouwen 1). Wanneer wij op dien voet nu den uitvoer van suiker gedurende de laatste 10 jaren opmaken dan verkrijgen wij voor dat tijdperk een middencijfer van 5.772 .500 pik. in het jaar, wat niet ver van de waarheid zijn kan. want volgens de door de regeering openbaar gemaakte productie-staten over de jaren 1881 tot en met 1889 (die over 1890 kan eerst over eenige maanden het licht zien) heeft de suikerproductie van Java bedragen

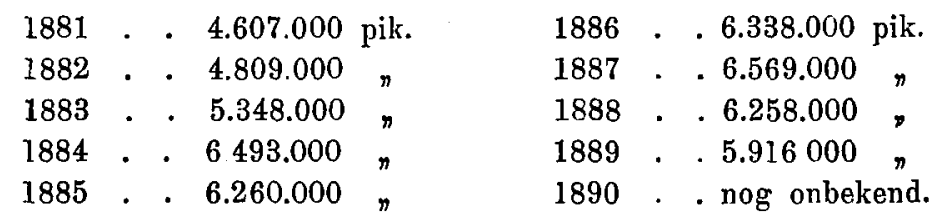

of gemiddeld 5.844.000 pik. per jaar, een verschil dus van 72.000 pik. meer met de uitgevoerde hoeveelheid, welk verschil zijne voor de hand liggende verklaring vindt in de omstandigheid, dat van de op Java geproduceerde suiker eene zekere hoeveelheid door de binnenlandsche consumtie verbruikt wordt, en dus niet bij den uitvoer in aanmerking komt. Als zeker mag men zelfs aannemen, dat die consumtie belangrijk meer dan 72,000 pik. in het jaar bedragen zal, want hoeveel moeite de regeering zich ook geeft voor de bijeenbrenging van juiste gegevens omtrent de opbrengst van alle suikerondernemingen op Java, volledig zijn deze nimmer. In werkelijkheid is de productie grooter dan de officieele productiecijfers aangeven.

1) In elk geval is de regeeringgopgaaf, wat het jaar 1889 betreft, zeer stellig foutief, en dit is te meer te betreuren omdat het daaxin voorkomende uitvoercijfer $\operatorname{van} 315.740 .000$ kilogr. of (als boven) 5.113.000 pikols reeds tot volkomen onjuiste gevolgtrekkingen geleid heeft. In het zeer onlangs verschenen werk van Dr. H. Passche, Zuckerindustrie und Zuckerhandel. der Welt (Jenr, 1891) wordt namelijk, in een op bl. 34.8 voorkomend overzicht. dat cijfer onveranderd overgenomen, en op bl. 417 daaraan niet zonder eenig leedvermaak de opmerking vastgoknoopt, dat de productie van Javà in 1889 bereids met éón derde beneden het een paar jaar geleden bereikte maximumcijfer van ruim 4 millioen tonnen gebleven is. 
De in 1889 en 1890 van Java uitgevoerde suiker vond, volgens de cijfers van de Handelsvereeniging, waaraan wij ons om de boven aangevoerde redenen wenschen te houden, haren weg als volgt:

\begin{tabular}{|c|c|c|c|c|c|c|c|c|}
\hline \multicolumn{5}{|c|}{ Naar } & \multicolumn{2}{|c|}{1889.} & \multicolumn{2}{|l|}{1890.} \\
\hline Nederland. & $\cdot$ & . & & & 57.000 & pik. & 124.000 & pik \\
\hline Engeland en $k$ & anaal & voor & ord & & .1148 .000 & $n$ & 992.000 & \\
\hline iddellandsche & zeeh & avens & & . & 224.000 & $n$ & & \\
\hline idem & voor & orders & & & 1.842 .000 & $\pi$ & 1.560 .000 & ᄁ \\
\hline Amerika & • & . . & & . & 940.000 & $\pi$ & 1.233 .000 & $n$ \\
\hline Australie . & . & . & 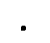 & & 586.000 & $n$ & $\mathbf{5 7 5 . 0 0 0}$ & \\
\hline China & . & . & . & 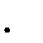 & 902.000 & » & 1.248 .000 & \\
\hline Singapore. & $0^{\circ}$ & • & . & $\cdot$ & 186.000 & $n$ & 398.000 & $n$ \\
\hline Britsch-Indie & . . & . . & . & . & - & $n$ & 49.000 & $n$ \\
\hline Elders in Azie & . & . $\cdot$ & . & - & - & $n$ & 1.000 & n \\
\hline
\end{tabular}

Derhalve werden verscheept

Naar

\begin{tabular}{|c|c|}
\hline Europa & 3.271 .000 pik \\
\hline Amerika & 940.000 \\
\hline Australie & 586.000 \\
\hline Azie . & 1.088 .000 \\
\hline
\end{tabular}

1890.

2.676.000 pik.

1.233 .000 n

575.000

1.696 .000

en vergelijkt men deze cijfers met die van een tiental jaren geleden, dan springt het in het oog welk een belangrijk afzetgebied voor zijne suiker Java in zijne onmiddellijke nabijheid gewonnen heett. Immers in 1879 en 1880 trokken de verschillende landen van Azië slechts respectievelijk 116.000 pik. en 119.000 pikols suiker van Java. Perzie deelde hierin voor 35.000 en 48.000 pikols; maar terwijl de uitvoer derwaarts geheel is te niet geloopen, heeft de vraag voor China in de laatste jaren een vlucht genomen, die te meer de aandacht verdient, omdat slechts weinige jaren geleden geen enkele pikol Java suiker derwaarts werd uitgevoerd.

Britsch-Indië ontving van Java in den loop van het vorige jaar 49,000 pik. suiker, en de aanvoer van deze op zich zelf vrij onbeduidende hoeveelheid schijnt aldaar 
niet zonder eenigen indruk te zijn gebleven, want in het rapport van de Bengal Central Railway Company limited over 1890 leest men o. a., dat de vermindering van het vervoer van inlandsche suiker uit het binnenland naar Calcutta moet worden geweten « to the displacement of Bengal-grown date sugar in the Calcutta market by Java-grown cane sugar. The date sugar bade fair to become a staple of traffic on this line, and this displacement was unfortunate. ) Het is intusschen bevreemdend, dat Britsch-Indie niet reeds aanmerkelijk meer suiker van Java trekt. De invoer aldaar van buitenlandsche suiker neemt gestadig toe, en klom in het dienstjaar $1889 / 90$ tot 1.723 .113 cwts., waarvan 195,346 cwts. weder werden uitgevoerd, zoodat het verbruik op 1.530 .000 cwts. of $1 \frac{1}{4}$ millioen pikols kan gesteld worden ${ }^{1}$ ) «Sugar», dus leest men op bl. 17 van O'Conor's Re view of the trade of India, “ comes from all parts now, chiefly from Mauritius, but cargoes were received from China, the Straits, Ceylon, England, Germany, France, Belgium and Austria.) Java, men ziet het, schittert door zijne afwezigheid in de rij, tenzij men mocht willen aannemen, dat de naar Singapore ten uitwoer aangegeven 398.000 pik. eigenlijk voor Britsch-Indie bestemd waren, wat zeker niet onmogelijk is; maar al is dit het geval geweest, dan blijft Britsch-Indie toch een gelegenheid tot afzet aanbieden, waarvan Java vermoedelijk nog meer partij kan trekken dan tot dus ver geschied is.

De uitvoeren naar Australie blijven ongeveer op dezelfde hoogte; maar die naar Amerika, welke in de jaren 1882/85 schier niets te beteekenen hadden, namen nu laatstelijk eene gewenschte uitbreiding, en er bestaat alle reden om te verwachten, dat onder de werking van de Mac Kinley wet de vraag van Amerika naar Java

\footnotetext{
1) Gedurende de elf eerste maanden van het op ult?. Maarb 11. geeindigde diensbjaar 1890/91 voerde Britsoh-Indie 2.708.300 owts. buitenlandsohe suiker, ter aangegeven waarde van Rn. 31.517.854, in.
} 
suiker eer toe dan afnemen zal, zoolang ten minste de door diezelfde wet beoogde begunstiging van de voortbrenging van inheemsche suiker de behoefte aan van elders herkomstige suiker niet belangrijk zal doen afnemen.

\section{KOFFIE.}

Sedert eenige jaren wordt een deel van de op Java voor particuliere rekening geteelde koffie in hoornschil verzonden om bij voorkeur hier in Nederland gepeld en aan de markt gebracht te worden. In de regeeringsstatistiek werd voor het eerst in 1885 van de ten uitvoer aangegeven gepelde en ongepelde koffie afzonderlijk melding gemaakt, en dienaangaande zijn thans de volgende cijfers beschikbaar:

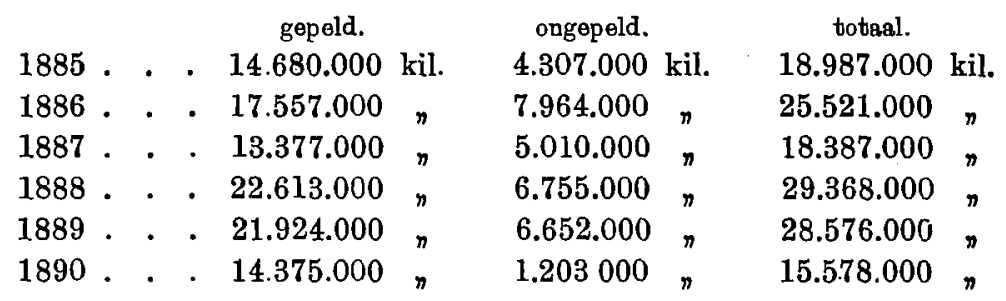

Bij herleiding van de totalen in pikolgewicht verkrijgt men de volgende hoeveelden:

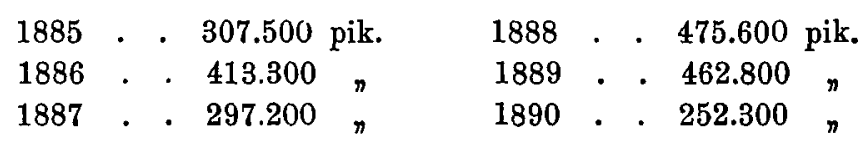

welke cijfers slechts zeer weinig verschillen met die van de Handelsvereeniging, want volgens hare, geheel onafhankelijk van de regeeringsstatistiek samengestelde opgaven zou de uitvoer van koffie hebben bedragen in

\begin{tabular}{|c|c|c|c|c|}
\hline 1885 & 299.300 & & 1888 & 475.200 \\
\hline 1886 & 418.900 & & 1889 & 483.100 \\
\hline 1887 & 319.200 & & 1890 & 276.900 \\
\hline
\end{tabular}

De cijfers van de Handelsvereeniging zijn doorloopend iets hooger; maar in doorslag bedraagt het verschil niet meer dan ruim 10,000 pikols in het jaar. 
Onder den particulieren koffieuitvoer zijn ook begrepen de telken jare tot een bedrag van 100,000 pikols of ca $^{\text {a }}$ 6.175.000 kilogrammen op Java in publieke veiling verkochte Gouvernements koffie, en met deze hoeveelheid moeten dus de boven medegedeelde cijfers worden verminderd om te komen tot het cijfer van den uitvoer der voor particuliere rekening geteelde koffie. Bij vergelijking nu van dat cijfer met de productie-opgaven van de Regeering, blijkt te hebben bedragen

\begin{tabular}{|c|c|c|c|}
\hline \multirow{3}{*}{ in 1885} & \multicolumn{2}{|c|}{ de uitvoer. } & \multirow{2}{*}{$\begin{array}{l}\text { de produotie. } \\
219.000 \text { pik. }\end{array}$} \\
\hline & 199.300 & pik. & \\
\hline & 318.900 & . & 273.000 \\
\hline 1887 & . . 219.200 & $n$ & 158.000 \\
\hline n 1888 & 375.200 & $n$ & 341.000 \\
\hline${ }_{n} 1889$ & . 383.100 & $n$ & 365.000 \\
\hline$\eta 1890$ & . 176.900 & $n$ & nog onbekend. \\
\hline
\end{tabular}

zoodat de uitvoer van de jaren 1885/89 de opgegeven productie met niet minder dan 148.000 pik. heeft overtroffen, een verschil dat zijne verklaring vindt, behalve in de onvolledigheid der productie-opgaven, in de mede onder den uitvoer begrepen cijfers van de op Java uit andere oorden in den archipel aangebrachte koffie, zooals de te Batavia geregeld verhandeld wordende Lahat-koffie van Palembang, en de te Soerabaja ter markt komende Balien Celebes-koffie, het produkt van de eigen cultuur van de inlandsche bevolking aldaar. Op Java zelf is van eene dergelijke vrije koffiecultuur tot $\mathrm{nu}$ toe geen sprake, omdat de bevolking verplicht is al de door haar ingezamelde koffie te leveren aan het Gouvernement tegen p. m. één vierde van den tegenwoordigen marktprijs. De particuliere Java-koffie is dan ook zonder eenige uitzondering afkomstig van de door Europeesche landbouwondernemers aangelegde aanplantingen.

Zooals straks reeds in het voorbijgaan werd aangetoond gaat nagenoeg al de ongepelde koffie naar Nederland: slechts een zeer kleine hoeveelheid wordt naar elders 
verzonden. Doch ook van de gepelde koffie ontvangt Nederland het leeuwendeel, want de uitvoer daarvan geschiedde, volgens de gegevens van de regeeringsstatistiek, waarvan wij ons in dit geval bedienen moeten, wijl daarin de uitvoer van gepelde en ongepelde koffie afzonderlijk vermeld wordt:

1889.

1890.

Nederland . . . . 244.200 pik.

Engeland . . . . . 5.200 n

Frankrijk . . . . . 17.600 ,

Oostenrijk (Triest) . . 7600 n

Port Said voor orders . 41.900 n

172.000 pik.

Amerika.

9.300

Singapore . . . . 23.400 n

Hongkong . . . . 2.500 n

Australie - . . . 2.300 ,

Elders . . . . . 800 ”

2.600
10.200
2.200
13.200
12.700
16.600
1500
800
1.000

Voor de Java koffie blijft Nederland dus de hoofdmarkt, in scherpe tegenstelling met de Padang koffie, die op een kleine hoeveelheid na rechtstreeks haar weg vindt naar Amerika.

INDIGO.

Tusschen de uitvoercijfers van de Regeering en die van de Handelsvereeniging bestaat met betrekking tot dit artikel stceds een zeer belangrijk verschil, dat zijne verklaring vindt in de omstandigheid, dat de regeerings statistiek alleen rekening houdt met het netto gewicht van de uitgevoerde indigo, naar welk gewicht ook het uitgaand recht van / 0.10 per kilogram geheven wordt, terwijl de statistiek der Handelsvereeniging geregeld melding maakt van het bruto gewicht.

Volgens de regeeringscijfers nu heeft de uitvoer in 1890 bedragen 617.167 kilogrammen, hetgeen een niet onbelangrijke teruggang aantoont tegenover de cijfers van de voorafgaande jaren, waarin een gestadige voor- 
uitgang viel waar te nemen. Van $\$ 15.000$ kilogrammen in 1881 steeg de uitvoer geleidelijk tot 601.000 in 1885 en bedroeg sedert in

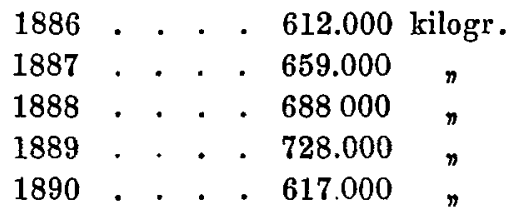

De vermindering van 1890 is geen gevolg van ink rimping van den aanplant, maar van den tegenspoed, waarmede de planters wegens ongunstige weersgesteldheid en de gevreesde rupsenplaag te kampen hadden.

Nagenoeg al de voor de Europeesche markt bereide indigo werd naar Nederland afgescheept, en wel tot een hoeveelheid van

$$
\begin{aligned}
& \text { in 1886. . . . } 585.000 \text { kilogr. } \\
& \eta 1887 . \text {. . . } 607.000 \text { n } \\
& \pitchfork \text { 1888. . . . } 630.000 \text { n } \\
& \text { n 1889. . . . } 634.000 \text { n } \\
& \text { n } 1890 \text {. . . } 547.000 \text { n, }
\end{aligned}
$$

Het overblijvende vond grootendeels zijn weg naar Middellandsche zee havens.

Als tak van zuiver inlandschen landbouw is de indigocultuur niet geheel zonder beteekenıs; doch volgens de Koloniale Verslagen wordt er, wegens den toenemenden invoer van goedkoope buitenlandsche lijnwaden en garens minder werk van gemaakt dan vroeger. Het verkregen product, de zoogenaamde natte indigo, dient hoofdzakelijk tot eigen gebruik, of wordt als ruwe grondstof op de passers van de hand gezet, doch met dat al is de uitvoer, die nagenoeg uitsluitend naar Singapora plaats vindt, stijgende, want hij bedroeg in:

$1881-85$. . . . 326.000 kil. gem. per jaar.

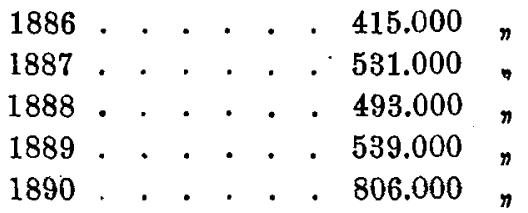


De uitvoer van indigo uit Britsch Indıë bleef in de laatste jaren tamelijk stationnair, bedragende in:

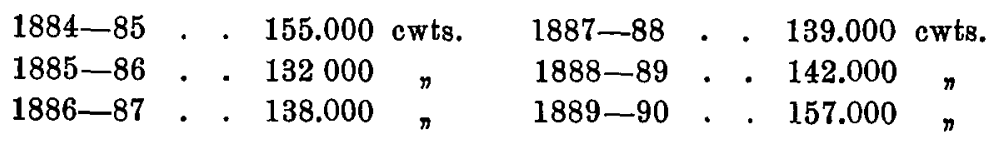

doch het laatste oogstjaar schijnt ook daar minder gunstige uitkomsten te hebben opgeleverd, want gedurende de eerste elf maanden van de ondervolgende dienstjaren bedroegen de uitvoeren:

$$
\begin{aligned}
& \text { 1888-89 . . } 133.000 \text { cwts. } \\
& 1889-90 \text {. . } 147.000 \text { n } \\
& 1890-91 \text {. . } 112.000 \text { n }
\end{aligned}
$$

TABAK.

De uitvoer van tabak voor de Europeesche markt bereid toont in 1890 weder eenigen vooruitgang aan, want hij bedroeg in:

$$
\begin{aligned}
& 1886 \text {. . } 9.610 .000 \text { kil. } \\
& 1887 \text {. . } 11.292 .000 \text {, } \\
& 1888 \text {. . } 12.199 .000 \text { n } \\
& 1889 \text {. . } 14.989 .000 \text { " } \\
& 1890 \text {. . } 15.886 .000 \text { n }
\end{aligned}
$$

welke cijfers vrij wel overeenkomen met de opgaven van de Handelsvereeniging, $\mathrm{nml}$.

$$
\begin{aligned}
& 1886 \text {. . } 163249 \text { pik. of } 10.040 .000 \text { kil. } \\
& 1887 \text {. } 185.880 \text { n } 11.470 .000 \text { n } \\
& 1888 \text {. } 193.406 \text { n } 11.945 .000 \text { n } \\
& 1889.240 .902 \text { \# } 14.876 .000 \text { n } \\
& 1890 \text {. } 244.978 \text { \# } 15.127 .000 \text { " }
\end{aligned}
$$

Daarentegen is er hoegenaamd geen verband te ontdekken tusschen de uitvoercijfers en de productie opgaven, zooals die in de Koloniale Verslagen voorkomen en tot en met 1888 geresumeerd zijn op bl. 40 van de Jaarcijfers van het Statistisch Instituut No. 8, want volgens die opgaven zou de productie slechts hebben bedragen (bladtabak en krossoks te samen) in 


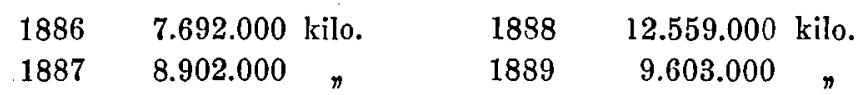

Voor deze zoo uiteenloopende cijfers is geen andere verklaring te vinden dan de onvolledigheid der ontvangen productieopgaven, waarover in de regeeringsverslagen zoo herhaaldelijk geklaagd wordt.

Al de van Java verscheepte tabak gaat naar Nederland, voor zoover zij door particuliere ondernemers voor de Europeesche markt bereid wordt; maar de door de bevolking geteelde tabak voor eigen gebruik en voor de inlandsche markt vormt ook een niet onbelangrijk artikel van handel, dat voor den uitvoer naar Singapore en China steeds zeer gezocht is, en wel in toenemende mate, want de uitvoer derwaarts bedroeg in

\begin{tabular}{|c|c|c|}
\hline $1881 / 85$ & 278.000 & kil. gem. per jaar \\
\hline 1886 & 501.000 & $n$ \\
\hline 1887 & 906.000 & $n$ \\
\hline 1888 & 916.000 & 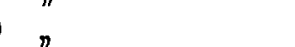 \\
\hline 1890 & 900.000 & 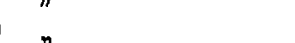 \\
\hline
\end{tabular}

SPECERIJEN.

Op Java zelf is de productie van noten en foelie, en ook van nagelen zoo hoogst onbeteekenend, dat zij voor den handel zoo goed als geen waarde heeft. Zij bedroeg in 1882 niet meer dan $\mathrm{c}^{\mathrm{a}} \mathbf{1 4 . 0 0 0}$ kilogr. noten, 3000 kil. foelie en 7000 kil. nagelen. Wat van Java werd uitgevoerd, was dan ook schier geheel uit de Molukken herkomstig, en daar nu laatstelijk de verzending van de Molukken naar Nederland, dat nog steeds de hoofdmarkt blijtt voor de Moluksche specerijen, grootendeels op doorconnossement geschiedt, en van tijdelijken opslag in een haven van Java veel minder sprake is dan vroeger, wijzen de uitvoercijfers van Java een zeer belangrijke vermindering in vergelijking met eenige jaren geleden aan. De uitvoer bedroeg 


\begin{tabular}{rrrlll} 
& \multicolumn{2}{c}{ van Noten } & & \multicolumn{2}{c}{ van Foelie } \\
in 1880 & 324.000 & kil. & 115.000 & kil. \\
"1881 & 375.000 & $n$ & 139.000 & " \\
"1889 & 59.000 & $n$ & 3.000 & " \\
" 1890 & 78.000 & n & 11.000 & n
\end{tabular}

Van de uitgevoerde peper is alleen de zwarte peper voor den handel van eenige betcekenis, want de uitvoer van stáartpeper (cubeben), -.. een artikel dat alleen op Java schijnt tehuis te behooren, - bepaalt zich tot eene hoeveelheid van een duizend à twee duizend pikols in het jaar. De uitvoer van zwarte peper daarentegen bedroeg in

$\begin{array}{lrlrrr}1885 & 970.000 & \text { kil. } & 1888 & 1.846 .000 & \text { kil. } \\ 1886 & 2.487000 & n & 1889 & 2.837 .000 & n \\ 1887 & 1.315000 & n & 1890 & 1.978 .000 & n\end{array}$

welke cijfers vrij wel overeenstemmen met de statistiek van de Handelsvereeniging, en dus als vertrouwbaar kunnen worden aangenomen.

Java zelf brengt op het oogenblik nog geen zwarte peper in eenige naamwaardige hoeveelheid aan de markt. $\mathrm{Al}$ het uitgevoerde is herkomstig van andere gewesten in den archipel, en wel voornamelijk van de Lampongsche districten, waar de pepercultuur zich gaandeweg uitbreidt, en in 1889 eene productie verkregen werd, die op p. m. 50.000 pik. geschat wordt, waarvoor de bevolking dus, bij een middenprijs van $f 25$ per pikol, p. m. $\int 1:$ millioen in contant geld in handen heeft gekregen. De pepercultuur is een van de voornaamste bronnen van bestaan voor de bevolking van de Lampongs geworden, en het is te hopen dat mettertijd hetzelfde zal kunnen getuigd worden van Bantam als ultkomst van de pogingen door de Regeering in het werk gesteld om de pepercultuur bij de bevolking aldaar meer ingang te doen vinden, waaromtrent in het Kol: Verslag van 1890 br. 185 eenige bijzonderheden worden medegedeeld.

Slechts een betrekkelijk gering deel van de uitgevoerde 
peper vindt zijn weg naar Nederland, want volgens de regee ringstatistiek werd verzonden in

$\begin{array}{lcccc}\quad \text { naar } & 1889 & 1890 & \\ \text { Nederland } & 414.000 & \text { kil. } & 314.000 & \text { kil. } \\ \text { Frankrijk } & 336.000 & n & 219.000 & n \\ \text { Italie } & 735.000 & n & 234.000 & n \\ \text { Overig Europa } & 602.000 & n & 528.000 & n \\ \text { Amerika } & - & & 118.000 & n \\ \text { Singapore } & 751.000 & & 520.000 & n \\ \quad \text { elders } & - & & 46.000 & \end{array}$

BOSCHPRODUCTEN.

Met uitzondering van gom dammar, waarvan de uitvoer in 1890 terugliep tot $1.182 .000 \mathrm{kil}$, tegen 1.311 .000 kil. in 1889, terwijl hij in de vijf daaraan voorafgaande jaren gemiddeld $1.056 .000 \mathrm{kil}$. bedroeg, spelen de zoogenaamde boschproducten, die allen schier zonder uitzondering van de buitenbezittingen herkomstig zijn, slechts een zeer ondergeschikte rol in het handelsverkeer van Java, of liever van Batavia, want het is daar voornamelijk, dat de van elders aangevoerde gom-dammar, gom-elastiek en getah-pertje ter markt wordt gebracht. Slechts van een kleine partij gom-elastiek uit de Preanger-regentschappen afkomstig vinden wij daarbij melding gemaakt.

De uitgevoerde gom-dammar had de volgende bestemming

\begin{tabular}{lrlll}
\multicolumn{1}{c}{ naar } & 1889 & \multicolumn{2}{c}{1890} \\
Nederland & 428.000 & kil. & 409.000 & kil. \\
Overig Europa & 626.000 & & 465.000 & $n$ \\
Amerika & 151.000 & $n$ & 122.000 & $n$ \\
Singapore & 103.000 & & 184.000 &
\end{tabular}

RIJST.

Even als de invoer van buitenlandsche rijst op Java kenmerkt de uitvoer van inheemsche rijst zich door 
zeer groote fluctuatiën, die in hoofdzaak verband houden met de meerdere of mindere opbrengst van den oogst, zooals uit onderstaand overzicht blijken kan (in pikols) :

\begin{tabular}{ccrr} 
& Oogst 1) & \multicolumn{1}{c}{ Invoer } & \multicolumn{1}{c}{ Uitwoer } \\
$1881 / 3$ & 30.013 .000 & 2.075 .000 & 95.000 \\
1884 & 34.205 .000 & 1.014 .000 & 167.000 \\
1885 & 35.820 .000 & 477.000 & 444.000 \\
1886 & 34.296 .000 & 15.000 & 930.000 \\
1887 & 34.940 .000 & 7.000 & 1.164 .000 \\
1888 & 33.120 .000 & 152.000 & 1.001 .000 \\
1889 & 31.948 .000 & 451.000 & 485.000 \\
1890 & $?$ & 742.000 & 436.000
\end{tabular}

Terwijl bij den invoer nu slechts twee landen van herkomst in aanmerking komen, namelijk Siam en Cochinchina, verdeelt de uitvoer zich in zeer uiteenloopende hoeveelheden over Nederland, Engeland, Australië en Singapore als volgt gedurende de laatste vijf jaren (in duizendtallen van pikols):

$\begin{array}{lrrrrr}\quad \text { naar } & 1886 & 1887 & 1888 & 1889 & 1890 \\ \text { Nederland } & 197 & 247 & 292 & 249 & 344 \\ \text { Engeland } & 92 & 33 & 42 & 33 & 12 \\ \text { Australie } & 4 & - & - & - & 1 \\ \text { Singapore } & 622 & 838 & 632 & 192 & 66 \\ \quad \text { elders } & 15 & 46 & 20 & 12 & 13\end{array}$

Bij ruime oogsten, zooals in 1886 en 1887, wanneer het er op aankomt om hetgeen Java meer produceert dan het voor zijne consumtie noodig heeft, best mogelijk van de hand te zetten, blijkt Singapore en via Singapore misschien ook China, het aangewezen débouché te zijn. Bij middelmatige oogsten, zooals nu laatstelijk het geval was, houden de uitvoeren naar Singapore op, of verminderen althans zeer; maar tegelijker tijd ziet men den uitvoer naar Nederland toenemen, eene oogenschijnlijke tegenstrijdigheid, die te verklaren is door de

1) Volgens de opgaven van het Koloniaal Verslag, 2 pik. padi gclijkstellende met I pikol gepelde rijet. 
omstandigheid, dat onafhankelijk van de resultaten van den oogst de zoogenaamde tafelrijst, en andere superieure qualiteiten steeds een gereeden aftrek op de Nederlandsche markt vinden. Toch maken de aanvoeren van Java slechts een betrekkelijk gering onderdeel uit van de hoeveelheden rijst, die Nederland jaarlijks invoert ${ }^{1}$ ) en voor eigen gebruik of voor uitvoer naar elders noodig heeft, en voor Java's bevolking ware het zeker te wenschen, dat zij zich een grooter aandeel in den wereldhandel in rijst kon verwerven dan dit thans nog het geval is. Het blijkt meer en meer dat Java op dit gebied een product kan leveren, dat volkomen geschikt is voor verzending naar Europa; maar eigenlijk is men in dit opzicht nog niet veel verder gekomen dan zeventig jaren geleden, toen de Minister van Onderwijs, Nijverheid en Koloniën A. R. Falck den Koning in een ambtsbrief van 12 September 1819 rapporteerde, dat de Java rijst, die voorheen niet dan toevallig als scheepsprovisie en in kleine hoeveelheid in Nederland werd aangevoerd, had opgehouden ween incourant en geen speculatie waardig artikel te zijn", sedert door den aanvoer van meerdere "volle ladingen" het artikel sschier bij den dag voorvloediger is geworden" 2). Ware Java van toen af geworden wat het zijn kon, een bij uitnemendheid rijst uitvoerend land, dan zou de economische ontwikkeling van land en volk niet onwaarschijnlijk een geheel anderen keer hebben genomen dan daaraan door de invoering en de uitbreiding van de gedwongen en geheel onevenredig betaalde koffiecultuur is gegeven.

1) Die invoer bedroeg in balen:

$\begin{array}{ccccc} & \text { Jave tafel } & \text { Javi } & \text { van elders } & \text { totaal } \\ 1888 & 160.000 & 22.000 & 1.194 .000 & 1.376 .000 \\ 1889 & 138.000 & 46.000 & 1.131 .000 & 1.315 .000 \\ 1890 & 108.000 & 145.000 & 1.051 .000 & 1.304 .000\end{array}$

2) Ambtsbrieven van A. R. Falck (180\%-1848); 's-Gravenhage, 1878; bl. 126 . 
THEE.

Even als de tabak is het artikel thee voor den eigenlijken uitvoerhandel van Java van slechts ondergeschikt belang, omdat nagenoeg het geheele product voor planters rekening naar Europa wordt verzonden, en slechts eene betrekkelijk geringe hoeveelheid op Java zelf wordt te gelde gemaakt. Een deel hiervan gaat over in de consumtie, terwijl het overige in sterk afwisselende hoeveelheden plaatsing vindt bij Armenische handelaren voor uitvoer naar Perzië.

De totale uitvoer van thee bedroeg, volgens de opgaven van de regeeringsstatistiek, waarmede die van de Handelsvereeniging vrij wel overeenstemmen, in:

$\begin{array}{llllll}1883 & 2.660 .000 & \text { kil. } & 1887 & 3.194000 & \text { kil. } \\ 1884 & 2533.000 & n & 1888 & 3.399 .000 & n \\ 1885 & 2.422 .000 & n & 1889 & 3.492 .000 & n \\ 1886 & 3.357 .000 & n & 1890 & 3.210 .000 & n\end{array}$

en die uitvoer vond plaats

naar

1889

1890

Nederland

1.885 .000 kil.

1.368 .000 kil.

Engeland

Singapore

1.467 .000

67000

elders

73.000

1.036 .000 n

$805.000 \pi$

1.000 n

Als vrij zeker kan men aannemen, dat de ten uitvoer naar Singapore aangegeven thee bestemd was voor Perzië, even als hetgeen onder het hoofd mnaar elders" vermeld staat, want niet aanneembaar is het, dat, zooals de officiëele jaarstatistiek voor 1889 aangeeft, ruim 23000 kil. Java thee naar China zouden zijn verzonden. Past men dezelfde conjectuur nu ook op vroegere jaren toe dan zou Perzië van Java hebben getrokken in

\begin{tabular}{ccccccc}
1883 & 114.000 & kil. & 1887 & 342.000 & kil. \\
1884 & 125.000 & $n$ & 1888 & 130.000 & & \\
1885 & 138.000 & $n$ & 1889 & 140.000 & $n$ & \\
1886 & 135.000 & $n$ & 1890 & 805.000 & $n$ & \\
CON. 1891. & & & & & & \\
\hline
\end{tabular}


thee, die grootendeels via Singapore en Bombay hun weg derwaarts vonden. In de reeds meermalen aangehaalde handelsverslagen van $O^{\prime}$ Connor wordt er sedert jaren over geklaagd, dat de Britsch-Indische theeplanters zich op de Perzische markt den loef hebben laten afsteken door hunne collega's op Java, en het mag een voor dezen verblijdend verschijnsel genoemd worden, dat zij blijkens de uitvoercijfers van 1890 (aan de juistheid waarvan niet behoeft te worden getwijfeld, want de opgaaf van de Handelsvereeniging is slechts 6000 kil. minder dan die van de Regeering), met zoo gunstig gevolg de mededinging op dit gebied weten vol te houden.

Intusschen mag niet over het hoofd worden gezien, dat de in 1890 zoo belangrijk toegenomen uitvoer van thee naar Perzië voor een goed deel te danken is aan de verbeterde koersverhoudingen met Britsch-Indie tengevolge van de tijdelijke stijging der zilverprijzen.

KINABAST.

Ook in dit voor de Nederlandsche markt zoo gewichtig geworden artikel wordt op Java zelf geen handel gedreven. Het wordt zonder eenige uitzondering voor rekening van de eigenaars der kinaplantages verscheept, in gestadig toenemende hoeveelheden, want de uitvoer bedroeg in

\begin{tabular}{|c|c|c|c|}
\hline 1884 & 203.000 kil & 1887 & 1.104 .000 \\
\hline 1885 & 488.000 & 1888 & 1.631 .000 \\
\hline 1886 & $832.000 n$ & 1889 & 2.257 .000 \\
\hline
\end{tabular}

en derhalve is de uitvoer in het afgeloopen jaar gestegen tot het veertienvoud van zeven jaren geleden. Gold het een artikel van algemeen verbruik, zooals dit met rijst, suiker, koffie en thee het geval is, men zou zich in het belang van Java slechts kunnen verheugen over eene zoo aanzienlijke vermeerdering van een van zijne uitvoer- 
producten; maar met kina is het anders gesteld. Het verbruik is beperkt, en ofschoon toenemende, houdt het allerminst gelijken tred met de toenemende productie, en dat onder den invloed van dien loop van zaken de prijs van het artikel steeds daalt, en nog verder dalen zal, kan door geen kunstmiddelen, zooals het vormen van syndicaten en andere manoeuvres, worden tegengehouden.

\section{ARAK.}

De uitvoer van arak bedroeg in 1890 niet meer dan 1.127.000 liters, het laagst bekende cijfer sedert vele jaren, want terwijl in 1875/78 gemiddeld per jaar 5.138 .000 liters en in de vier volgende jaren 1879/82 nog 3.390 .000 liters werden uitgevoerd, bepaalde die uitvoer zich tot

$\begin{array}{llllll}1883 & 2.401 .000 & \text { liter } & 1887 & 3.648 .000 & \text { liter } \\ 1884 & 3.899 .000 & & 1888 & 1.753 .000 & \\ 1885 & 3.621 .000 & n & 1889 & 2.133 .000 & n \\ 1886 & 2.267 .000 & n & \text { i } 890 & 1.127 .000 & n\end{array}$

Van de uitgevoerde hoeveelheden ontving Nederland

in $\begin{array}{rrc}1886 & 1.500 .000 & \text { liters } \\ 1887 & 2.506 .000 & n \\ 1888 & 647.000 & n \\ 1889 & 1.344 .000 & n \\ 1890 & 394.000 & n\end{array}$

De rest vindt zijn weg nagenoeg geheel naar Singapore en Timor-Deli. Naar andere landen in Europa gaat zoo goed als niets.

\section{KAPOK.}

De uitvoer van dit artikel, waarvan indertijd groote verwachtingen werden gekoesterd, blijft stationnair, en bedroeg in

$\begin{array}{cccccc}1887 & 1.217 .000 & \text { kil. } & 1889 & 1.103 .000 & \text { kil. } \\ 1888 & 1.657 .000 & n & 1890 & 1.570 .000 & n\end{array}$

waarvan Nederland ontving in 


$\begin{array}{llllll}1887 & 758.000 & \text { kil. } & 1889 & 588.000 & \text { kil. } \\ 1888 & 687.000 & n & 1890 & 805.000 & \end{array}$

Te Singapore en in Australië vindt de overblijvende hoeveelheid plaatsing.

Ook Ceylon voert kapok uit (onder den naam van (cotton wool»), (much to the benefit of the natives in the Western, North-Western and central provinces», zooals op bl. 120 van Ferguson's Ceylon Handbook and Directory for 1890/91 wordt opgemerkt; maar veel heeft die uitvoer niet te beduiden, want hij bedroeg slechts

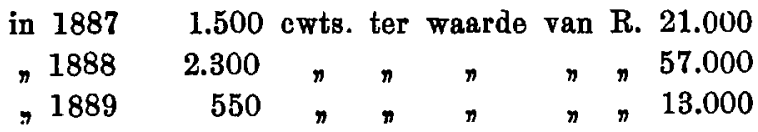

De uitvoer van kapok uit Britsch-Indië is vermoedelijk van niet veel meer beteekenis, want in de handelsstatistiek wordt er geen afzonderlijke melding van gemaakt.

COPRA.

Dit artikel, dat in de maandelijksche regeeringsstatistiek niet is opgenomen, begon eenigen tijd geleden onder de uitvoeren van Java een niet geheel onbelangrijke rol te spelen, maar volgens de opgaven van de Handelsvereeniging heeft het reeds veel van zijne beteekenis verloren, want de uitvoer bedroeg

\begin{tabular}{|c|c|}
\hline in 1888 & 128.000 \\
\hline 1889 & 93.000 \\
\hline \# 1890 & 22.000 \\
\hline
\end{tabular}

Misschien echter is hierbij een vergissing in het spel; want in het jongste Koloniaal Verslag leest men op bl. 185, dat de uitvoer van klapperolie en copra naar Europa en Singapore belangrijk toenam, voornamelijk uit Bantam en Cheribon. 
III.

«Een bevredigende indruk zal het geleverde overzicht van de voornaamste invoer en uitvoerartikelen van Java gedurende de laatste acht jaren niet achterlaten.) Dit was de slotsom van een ter gelegenheid van de in 1883 te Amsterdam gehouden Koloniale tentoonstelling door mij uitgegeven geschrift ${ }^{1}$ ), en met betrekking tot het sedert weder verloopen achtjarig tijdperk kan onze uitspraak helaas niet veel gunstiger luiden. Op slechts enkele schaarsche uitzonderingen na valt gedurende de laatste zestien jaren eigenlijk geen spoor van wezenlijken, blijvenden vooruitgang te ontdekken; in het algemeen gesproken bleef èn invoer èn uitvoerhandel niet veel meer dan stationnair, en dit niettegenstaande de zeer aanzienlijke vermeerdering van Java's bevolking, want van ruim 18.125.000 zielen aan het eind van 1874 was zij volgens de cijfers van het jongste Koloniaal Verslag bij het eind van 1888 tot 22.820 .000 zielen en dus met 26 pCt. gestegen. Het wordt bij een dergelijken aanwas der bevolking een inderdaad onrustbarend verschijnsel, dat niet blijkt van eene daarmede verband houdende uitbreiding van de middelen van bestaan, want de voor Java's bevolking zoo onwaardeerbare uitbreiding van de suikerindustrie, een van de weinige lichtpunten waarop in ons overzicht kon gewezen worden, komat daaraan zeker niet op voldoende wijze te gemoet. Toch mag het een zegen heeten, dat in dit opzicht althans op werkelijk deugdelijken vooruitgang kan worden gewezen, want men huivert onwillekeurig bij de gedachte aan den toestand, waarin Java zou verkeeren, indien het deze bron van volkswelvaart kwam te derven. Werd Java eenmaal, en niet ten onrechte, de kurk genaamd, waarop Nederland een tijd lang dreef, Java's huishouding van staat drijft

1) De handel van Java gedurende de lagtate acht jaron; Batavia, G. Kolff on Co, , 1883. 
tegenwoordig meer dan ooit op de suiker in de allereerste plaats, en op de overige producten, met de teelt waarvan de door Europeesche ondernemers gedreven groote landbouw zich onledig houdt. De millioenen, dıe in den vorm van allerlei belastingen en heffingen jaarlijks in 's lands schatkist vloeien, zijn voor een zeer groot deel de vrucht van de op Java bestaande particuliere landbouw en nijverheids-ondernemingen, en naarmate de baten, op het geregeld binnenkomen waarvan de schatkist in vroeger jaren staat kon maken, wegvallen of verminderen, wordt het eene wezenlijke levensquaestie voor land en volk om door middel van die ondernemingen en van den eigen landbouw der inheemsche bevolking de voortbrengende krachten van het land tot meerdere ontwikkeling te brengen.

Dit is $\mathrm{m}$. $i$. op het oogenblik de koloniale quaestie bij uitnemendheid, van wier berredigende oplossing de toekomst van Java grootendeels zal afhangen. Hoe veel men ook gevoelen moge voor de met afwisselenden aandrang op den voorgrond tredende vraagstukken van hoogere politiek, voor zelfbestuur, voor decentralisatie, voor betere vertegenwoordiging van de koloniale belangen in de wetgevende vergadering van het moederland, voor de instelling van een kolonialen raad in Nederland - in mijn oog de noodlottigste hervorming die aan Indië zou kunnen worden toegedacht - bij de verwezenlijking van geen dier plannen zal Indië eenige wezenlijke baat vinden zoolang niet alles uit den weg wordt geruimd wat zijne economische ontwikkeling tegenhoudt en belemmert. Vóór alles zij het streven van regeerders en geregeerden er op gericht om de voortbrenging in het algemeen, en de landbouwnijverheid in het bijzonder hetzij zij gedreven wordt door de inheemsche bevolking eigener beweging, of door Europeesche ondernemers met behulp van inlandschen loonarbeid, vrij te maken van knellende banden en lasten, want voortbrenging en 
volkswelvaart hangen onafscheidbaar samen, en het geldt hier niet alleen de welvaart van eene in veler oog ver verwijderde buitenlandsche bezitting, maar ook die van het moederland zelf, dat zijn tegenwoordigen bloei onbetwistbaar voor een goed deel aan Indië te danken heeft. De Indische baten toch stelden het weleer in staat om, zonder eigen geldelijke offers, al die groote werken en verbeterde gemeenschapsmiddelen tot stand te brengen, waarvan ons land thans de rijke vruchten plukt. Op dergelijke baten valt voor de toekomst in geen geval meer te rekenen; maar indirect zal Nederland zijn voordeel blijven doen met de meerdere welvaart, die voor Indië uit eene tot hooger trap opgevoerde ontwikkeling van zijne veelzijdige hulpbronnen moet voortvloeien.

Laat ons hopen, dat aan het eind van een volgend achtjarig tijdperk de cijfers der handelsstatistiek hiervan op welsprekende wijs zullen getuigen.

N. P. VAN DEN BERG. 